\title{
Unveiling the Physical and Functional Niches of FAM26F by Analyzing Its Subcellular Localization and Novel Interacting Partners
}

Uzma Malik, Saima Zafar, Neelam Younas, Inga Zerr, and Aneela Javed* https://dx.doi.org/10.1021/acsomega.0c01249

Table S1. Differentially expressed proteins between the control and transfected eluates, with the MS peptide count being higher for transfected eluate as compared to the control eluate.

\begin{tabular}{|c|c|c|c|c|c|}
\hline No. & $\begin{array}{l}\text { Protein } \\
\text { Name }\end{array}$ & $\begin{array}{l}\text { Accession } \\
\text { Number }\end{array}$ & $\begin{array}{l}\text { Molecular } \\
\text { weight }\end{array}$ & Function & Refs \\
\hline 1 & $\begin{array}{l}\text { Protein } \\
\text { S100-A99 }\end{array}$ & P06702 & $13 \mathrm{kDa}$ & $\begin{array}{l}\text { A calcium- and zinc-binding protein } \\
\text { which plays a prominent role in the } \\
\text { regulation of inflammatory processes and } \\
\text { immune response }\end{array}$ & $1-7$ \\
\hline 2 & Caspase-14 & P31944 & $28 \mathrm{kDa}$ & $\begin{array}{l}\text { Non-apoptotic caspase involved in } \\
\text { epidermal differentiation }\end{array}$ & 8,9 \\
\hline 3 & Cathepsin D & P07339 & $45 \mathrm{kDa}$ & $\begin{array}{l}\text { An acid protease active in intracellular } \\
\text { protein breakdown. }\end{array}$ & 10 \\
\hline 4 & Annexin A2 & P07355 & $39 \mathrm{kDa}$ & $\begin{array}{l}\text { Calcium-regulated membrane-binding } \\
\text { protein might be involved in heat-stress } \\
\text { response. Inhibits PCSK9-enhanced } \\
\text { LDLR degradation, probably reduces } \\
\text { PCSK9 protein levels but also competes } \\
\text { with LDLR for binding with PCSK9 }\end{array}$ & $11-13$ \\
\hline 5 & $\begin{array}{l}\text { Bleomycin } \\
\text { hydrolase }\end{array}$ & Q13867 & $53 \mathrm{kDa}$ & $\begin{array}{l}\text { Normal physiological role of BLM } \\
\text { hydrolase is unknown, but it catalyzes the } \\
\text { inactivation of the antitumor drug BLM } \\
\text { thus protecting normal and malignant } \\
\text { cells from BLM toxicity }\end{array}$ & $\begin{array}{l}\text { https://ww } \\
\text { w.uniprot. } \\
\text { org/uniprot } \\
\text { /Q13867 }\end{array}$ \\
\hline 6 & $\begin{array}{l}\text { Histidine } \\
\text { ammonia- } \\
\text { lyase }\end{array}$ & P42357 & $73 \mathrm{kDa}$ & $\begin{array}{l}\text { A cytosolic enzyme catalyzing the first } \\
\text { reaction in histidine catabolism, the } \\
\text { nonoxidative deamination of L-histidine } \\
\text { to trans-urocanic acid }\end{array}$ & $\begin{array}{l}\text { https://ww } \\
\text { w.uniprot. } \\
\text { org/uniprot } \\
\text { /P42357 }\end{array}$ \\
\hline
\end{tabular}




\begin{tabular}{|c|c|c|c|c|c|}
\hline 7 & $\begin{array}{l}\text { Cluster of } \\
\text { Serpin B3 }\end{array}$ & P29508 & $45 \mathrm{kDa}$ & $\begin{array}{l}\text { May act as a papain-like cysteine } \\
\text { protease inhibitor to modulate the host } \\
\text { immune response against tumor cells. } \\
\text { Also functions as an inhibitor of UV- } \\
\text { induced apoptosis via suppression of the } \\
\text { activity of c-Jun } \mathrm{NH}_{2} \text {-terminal kinase } \\
\text { (JNK1). }\end{array}$ & 14 \\
\hline 8 & $\begin{array}{l}\text { Protein } \\
\text { S100-A7 }\end{array}$ & P31151 & $11 \mathrm{kDa}$ & $\begin{array}{l}\text { Calcium-binding protein containing the } \\
\text { EF hand motif that displays antimicrobial } \\
\text { activities against bacteria and triggers } \\
\text { immunomodulatory activities }\end{array}$ & 15,16 \\
\hline 9 & $\begin{array}{l}\text { Protein } \\
\text { S100-A8 }\end{array}$ & P05109 & $11 \mathrm{kDa}$ & $\begin{array}{l}\text { A calcium- and zinc-binding protein } \\
\text { which plays a prominent role in the } \\
\text { regulation of inflammatory processes and } \\
\text { immune response. }\end{array}$ & $1,2,5,7,17$ \\
\hline 10 & $\begin{array}{l}\text { Glyceraldehy } \\
\text { de-3- } \\
\text { phosphate } \\
\text { dehydrogena } \\
\text { se }\end{array}$ & P04406 & $36 \mathrm{kDa}$ & $\begin{array}{l}\text { Plays a role in glycolysis and nuclear } \\
\text { functions. Component of the GAIT } \\
\text { (gamma interferon-activated inhibitor of } \\
\text { translation) complex which mediates } \\
\text { interferon-gamma-induced transcript- } \\
\text { selective translation inhibition in } \\
\text { inflammation processes }\end{array}$ & $18-20$ \\
\hline 11 & $\begin{array}{l}\text { Protein- } \\
\text { glutamine } \\
\text { gamma- } \\
\text { glutamyltran } \\
\text { sferase K }\end{array}$ & P22735 & 90 kDa & $\begin{array}{l}\text { Catalyzes the cross-linking of proteins } \\
\text { and the conjugation of polyamines to } \\
\text { proteins }\end{array}$ & 21 \\
\hline 12 & $\begin{array}{l}\text { Alpha-2- } \\
\text { macroglobuli } \\
\text { n-like protein } \\
1\end{array}$ & A8K2U0 & $161 \mathrm{kDa}$ & $\begin{array}{l}\text { Is able to inhibit all four classes of } \\
\text { proteinases by a unique 'trapping' } \\
\text { mechanism }\end{array}$ & 22 \\
\hline
\end{tabular}




\begin{tabular}{|c|c|c|c|c|c|}
\hline 13 & $\begin{array}{l}\text { Protein- } \\
\text { glutamine } \\
\text { gamma- } \\
\text { glutamyltran } \\
\text { sferase E }\end{array}$ & Q08188 & $77 \mathrm{kDa}$ & $\begin{array}{l}\text { Catalyzes the calcium-dependent } \\
\text { formation of isopeptide cross-links } \\
\text { between glutamine and lysine residues in } \\
\text { various proteins, as well as the } \\
\text { conjugation of polyamines to proteins }\end{array}$ & 23,24 \\
\hline 14 & Arginase-1 & P05089 & $35 \mathrm{kDa}$ & $\begin{array}{l}\text { Involved in an antimicrobial effector } \\
\text { pathway in polymorphonuclear } \\
\text { granulocytes (PMN). Upon PMN cell } \\
\text { death is liberated from the } \\
\text { phagolysosome and depletes arginine in } \\
\text { the microenvironment leading to } \\
\text { suppressed T cell and natural killer (NK) } \\
\text { cell proliferation and cytokine secretion }\end{array}$ & $25-27$ \\
\hline 15 & $\begin{array}{l}\text { Gamma- } \\
\text { glutamylcycl } \\
\text { otransferase }\end{array}$ & O75223 & $21 \mathrm{kDa}$ & $\begin{array}{l}\text { Induces release of cytochrome c from } \\
\text { mitochondria with resultant induction of } \\
\text { apoptosis. May play a significant role in } \\
\text { glutathione homeostasis }\end{array}$ & 28,29 \\
\hline 16 & $\begin{array}{l}\text { Polyubiquitin } \\
\text {-B }\end{array}$ & P0CG47 & $26 \mathrm{kDa}$ & $\begin{array}{l}\text { Involved in: DNA repair; in ERAD } \\
\text { (endoplasmic reticulum-associated } \\
\text { degradation) and in cell-cycle regulation; } \\
\text { in lysosomal degradation; in kinase } \\
\text { modification; in protein degradation via } \\
\text { the proteasome; in endocytosis, in DNA- } \\
\text { damage responses as well as in signaling } \\
\text { processes leading to activation of the } \\
\text { transcription factor NF-kappa- }\end{array}$ & 30,31 \\
\hline 17 & $\begin{array}{l}\text { Peroxiredoxi } \\
\text { n-2 }\end{array}$ & P32119 & $22 \mathrm{kDa}$ & $\begin{array}{l}\text { Plays a role in cell protection against } \\
\text { oxidative stress by detoxifying peroxides } \\
\text { and as sensor of hydrogen peroxide- } \\
\text { mediated signaling events. Might } \\
\text { participate in the signaling cascades of } \\
\text { growth factors and tumor necrosis factor- }\end{array}$ & 32 \\
\hline
\end{tabular}




\begin{tabular}{|c|c|c|c|c|c|}
\hline & & & & $\begin{array}{l}\text { alpha by regulating the intracellular } \\
\text { concentrations of } \mathrm{H}_{2} \mathrm{O}_{2}\end{array}$ & \\
\hline 18 & Filaggrin & P20930 & $435 \mathrm{kDa}$ & $\begin{array}{l}\text { Essential for the regulation of epidermal } \\
\text { homeostasis and is responsible for the } \\
\text { skin barrier function }\end{array}$ & 33,34 \\
\hline 19 & $\begin{array}{l}\text { Zinc-alpha- } \\
2- \\
\text { glycoprotein }\end{array}$ & P25311 & $34 \mathrm{kDa}$ & $\begin{array}{l}\text { Stimulates lipid degradation in } \\
\text { adipocytes and causes the extensive fat } \\
\text { losses associated with some advanced } \\
\text { cancers. Also involved in fertilization and } \\
\text { immuno-regulation. }\end{array}$ & $35-38$ \\
\hline 20 & Cystatin-A & P01040 & $11 \mathrm{kDa}$ & $\begin{array}{l}\text { An intracellular thiol proteinase inhibitor } \\
\text { having an important role in desmosome- } \\
\text { mediated cell-cell adhesion in the lower } \\
\text { levels of the epidermis. }\end{array}$ & 39 \\
\hline 21 & Gasdermin-A & Q96QA5 & 49 kDa & $\begin{array}{l}\text { May promote pyroptosis. Also binds to } \\
\text { bacterial and mitochondrial lipids, } \\
\text { including cardiolipin, and exhibits } \\
\text { bactericidal activity }\end{array}$ & 40 \\
\hline 22 & Galectin-7 & P47929 & $15 \mathrm{kDa}$ & $\begin{array}{l}\text { Could be involved in cell-cell and/or cell- } \\
\text { matrix interactions necessary for normal } \\
\text { growth control. Pro-apoptotic protein that } \\
\text { functions intracellularly upstream of JNK } \\
\text { activation and cytochrome c release. }\end{array}$ & 41 \\
\hline 23 & $\begin{array}{l}\text { Calpain-1 } \\
\text { catalytic } \\
\text { subunit }\end{array}$ & P07384 & $82 \mathrm{kDa}$ & $\begin{array}{l}\text { A non-lysosomal thiol-protease regulated } \\
\text { by Calcium that catalyzes partial } \\
\text { proteolysis of substrates required for } \\
\text { signal transduction and cytoskeletal } \\
\text { remodeling }\end{array}$ & 42,43 \\
\hline 24 & $\begin{array}{l}\text { Fructose- } \\
\text { bisphosphate } \\
\text { aldolase A }\end{array}$ & P04075 & $39 \mathrm{kDa}$ & $\begin{array}{l}\text { Plays a key role in glycolysis and } \\
\text { gluconeogenesis. May also function as } \\
\text { scaffolding protein. Proposed to }\end{array}$ & 44 \\
\hline
\end{tabular}




\begin{tabular}{|c|c|c|c|c|c|}
\hline & & & & $\begin{array}{l}\text { participate in the control of host redox } \\
\text { homeostasis and the inflammatory } \\
\text { immune response. }\end{array}$ & \\
\hline 25 & Catalase & P04040 & $60 \mathrm{kDa}$ & $\begin{array}{l}\text { Serves to protect cells from the toxic } \\
\text { effects of hydrogen peroxide. Promotes } \\
\text { growth of cells including T-cells, B-cells, } \\
\text { myeloid leukemia cells, melanoma cells, } \\
\text { mastocytoma cells and normal and } \\
\text { transformed fibroblast cells. }\end{array}$ & 45 \\
\hline 26 & Thioredoxin & P10599 & $12 \mathrm{kDa}$ & $\begin{array}{l}\text { Participates in various redox reactions } \\
\text { through the reversible oxidation of its } \\
\text { active center dithiol to a disulfide } \\
\text { (calcium dependent) and catalyzes } \\
\text { dithiol-disulfide exchange reactions. }\end{array}$ & 46 \\
\hline 27 & $\begin{array}{l}\text { F-box only } \\
\text { protein } 50\end{array}$ & Q6ZVX7 & $31 \mathrm{kDa}$ & Promotes cell proliferation. & 47 \\
\hline 28 & $\begin{array}{l}78 \quad \mathrm{kDa} \\
\text { glucose- } \\
\text { regulated } \\
\text { protein }\end{array}$ & P11021 & $72 \mathrm{kDa}$ & $\begin{array}{l}\text { Endoplasmic reticulum chaperone that } \\
\text { plays a key role in protein folding and } \\
\text { quality control in the endoplasmic } \\
\text { reticulum lumen }\end{array}$ & 48,49 \\
\hline 29 & $\begin{array}{l}\text { Calmodulin- } \\
\text { like protein } 5\end{array}$ & Q9NZT1 & $16 \mathrm{kDa}$ & $\begin{array}{l}\text { A calcium-binding regulatory protein } \\
\text { transmitting a momentary increase in the } \\
\text { concentration of intracellular calcium to } \\
\text { activation of specific enzymes }\end{array}$ & 50 \\
\hline 30 & $\begin{array}{l}\text { Protein } \\
\text { POF1B }\end{array}$ & Q8WVV4 & $68 \mathrm{kDa}$ & $\begin{array}{l}\text { Plays a key role in the organization of } \\
\text { epithelial monolayers by regulating the } \\
\text { actin cytoskeleton. May be involved in } \\
\text { ovary development }\end{array}$ & 51,52 \\
\hline 31 & $\begin{array}{l}\text { Ganglioside } \\
\text { GM2 } \\
\text { activator }\end{array}$ & P17900 & $21 \mathrm{kDa}$ & $\begin{array}{l}\text { Exhibits some calcium-independent } \\
\text { phospholipase activity. Binds } \\
\text { gangliosides and stimulates ganglioside }\end{array}$ & $\begin{array}{l}\text { https://ww } \\
\text { w.uniprot. } \\
\text { org/uniprot }\end{array}$ \\
\hline
\end{tabular}




\begin{tabular}{|c|c|c|c|c|c|}
\hline & & & & $\begin{array}{l}\text { GM2 degradation; stimulates only the } \\
\text { breakdown of ganglioside GM2 and } \\
\text { glycolipid GA2 by beta-hexosaminidase } \\
\text { A }\end{array}$ & /P17900 \\
\hline 32 & $\begin{array}{l}\text { Cluster of } \\
\text { Plectin }\end{array}$ & Q15149 & $532 \mathrm{kDa}$ & $\begin{array}{l}\text { Interlinks intermediate filaments with } \\
\text { microtubules and microfilaments and } \\
\text { anchors intermediate filaments to } \\
\text { desmosomes or hemidesmosomes. }\end{array}$ & 53 \\
\hline 33 & $\begin{array}{l}\text { Fatty acid- } \\
\text { binding } \\
\text { protein, } \\
\text { epidermal }\end{array}$ & Q01469 & $15 \mathrm{kDa}$ & $\begin{array}{l}\text { Selectively delivers specific fatty acids } \\
\text { from the cytosol to the nucleus, wherein } \\
\text { they activate nuclear receptors. Controls } \\
\text { retrograde endocannabinoid signaling. } \\
\text { Modulates inflammation }\end{array}$ & 54,55 \\
\hline 34 & $\begin{array}{l}\text { Carboxypepti } \\
\text { dase A4 }\end{array}$ & Q9UI42 & $47 \mathrm{kDa}$ & $\begin{array}{l}\text { Metalloprotease that functions in } \\
\text { neuropeptide processing and regulation in } \\
\text { the extracellular environment }\end{array}$ & 56 \\
\hline 35 & $\begin{array}{l}\text { Proteasome } \\
\text { subunit alpha } \\
\text { type-4 }\end{array}$ & P25789 & $29 \mathrm{kDa}$ & $\begin{array}{l}\text { Component of the } 20 \mathrm{~S} \text { core proteasome } \\
\text { complex involved in the proteolytic } \\
\text { degradation of most intracellular proteins. }\end{array}$ & $57-59$ \\
\hline 36 & $\begin{array}{l}\text { Proteasome } \\
\text { subunit alpha } \\
\text { type-3 }\end{array}$ & P25788 & $28 \mathrm{kDa}$ & $\begin{array}{l}\text { Component of the } 20 \mathrm{~S} \text { core proteasome } \\
\text { complex involved in the proteolytic } \\
\text { degradation of most intracellular proteins. } \\
\text { Binds to the C-terminus of CDKN1A and } \\
\text { thereby mediates its degradation. } \\
\text { Negatively regulates the membrane } \\
\text { trafficking of the cell-surface } \\
\text { thromboxane A2 receptor (TBXA2R) } \\
\text { isoform } 2\end{array}$ & $57-62$ \\
\hline 37 & $\begin{array}{l}\text { Malate } \\
\text { dehydrogena } \\
\text { se, }\end{array}$ & P40926 & $36 \mathrm{kDa}$ & $\begin{array}{l}\text { Essential for the conversion of malate to } \\
\text { oxaloacetate as part of the proper } \\
\text { functioning of the Krebs cycle }\end{array}$ & 63 \\
\hline
\end{tabular}




\begin{tabular}{|c|c|c|c|c|c|}
\hline & $\begin{array}{l}\text { mitochondria } \\
1\end{array}$ & & & & \\
\hline 38 & Vinculin & P18206 & $124 \mathrm{kDa}$ & $\begin{array}{l}\text { A key platelet protein which experiences } \\
\text { calcium dependent tyrosine } \\
\text { phosphorylation during the activation of } \\
\text { platelet }\end{array}$ & 64 \\
\hline 39 & $\begin{array}{l}\text { Proteasome } \\
\text { subunit alpha } \\
\text { type-7 }\end{array}$ & O14818 & $28 \mathrm{kDa}$ & $\begin{array}{l}\text { Component of the } 20 \mathrm{~S} \text { core proteasome } \\
\text { complex involved in the proteolytic } \\
\text { degradation of most intracellular proteins. } \\
\text { Inhibits the transactivation function of } \\
\text { HIF-1A under both normoxic and } \\
\text { hypoxia-mimicking conditions. Plays a } \\
\text { role in hepatitis C virus internal ribosome } \\
\text { entry site-mediated translation. Mediates } \\
\text { nuclear translocation of the androgen } \\
\text { receptor (AR) and thereby enhances } \\
\text { androgen-mediated transactivation. } \\
\text { Promotes MAVS degradation and } \\
\text { thereby negatively regulates MAVS- } \\
\text { mediated innate immune response. }\end{array}$ & $57-59,65-69$ \\
\hline 40 & $\begin{array}{l}\text { Eukaryotic } \\
\text { translation } \\
\text { initiation } \\
\text { factor } 6\end{array}$ & P56537 & $27 \mathrm{kDa}$ & $\begin{array}{l}\text { Involved in ribosome biogenesis. } \\
\text { Behaves as a stimulatory translation } \\
\text { initiation factor downstream } \\
\text { insulin/growth factors. Associates with } \\
\text { pre-60S subunits in the nucleus and is } \\
\text { involved in its nuclear export. Required } \\
\text { for ROS-dependent megakaryocyte } \\
\text { maturation and platelets formation, } \\
\text { controls the expression of mitochondrial } \\
\text { respiratory chain genes involved in } \\
\text { reactive oxygen species (ROS) synthesis } \\
\text { (By similarity). Involved in miRNA- }\end{array}$ & $70-73$ \\
\hline
\end{tabular}




\begin{tabular}{|c|c|c|c|c|c|}
\hline & & & & $\begin{array}{l}\text { mediated gene silencing by the RNA- } \\
\text { induced silencing complex (RISC). } \\
\text { Modulates cell cycle progression and } \\
\text { global translation of pre-B cells }\end{array}$ & \\
\hline 41 & $\begin{array}{l}\text { Proteasome } \\
\text { subunit beta } \\
\text { type-1 }\end{array}$ & P20618 & $26 \mathrm{kDa}$ & $\begin{array}{l}\text { Component of the } 20 \mathrm{~S} \text { core proteasome } \\
\text { complex involved in the proteolytic } \\
\text { degradation of most intracellular proteins. }\end{array}$ & $57-59$ \\
\hline 42 & $\begin{array}{l}\text { Lysosomal } \\
\text { protective } \\
\text { protein }\end{array}$ & P10619 & $54 \mathrm{kDa}$ & $\begin{array}{l}\text { Associates with both beta-galactosidase } \\
\text { and neuraminidase and exerts a protective } \\
\text { function necessary for their stability and } \\
\text { activity; a carboxypeptidase that can } \\
\text { deamidate tachykinins. }\end{array}$ & 74 \\
\hline 43 & $\begin{array}{l}\text { Lysosome- } \\
\text { associated } \\
\text { membrane } \\
\text { glycoprotein } \\
1\end{array}$ & P11279 & $45 \mathrm{kDa}$ & $\begin{array}{l}\text { Presents carbohydrate ligands to } \\
\text { selectins. Also implicated in tumor cell } \\
\text { metastasis. Acts as a receptor for Lassa } \\
\text { virus protein. }\end{array}$ & 75 \\
\hline 44 & $\begin{array}{l}\text { Proteasome } \\
\text { subunit alpha } \\
\text { type- } 6\end{array}$ & P60900 & $27 \mathrm{kDa}$ & $\begin{array}{l}\text { Component of the } 20 \mathrm{~S} \text { core proteasome } \\
\text { complex involved in the proteolytic } \\
\text { degradation of most intracellular proteins. }\end{array}$ & $57-59$ \\
\hline
\end{tabular}

\section{References}

1. Ryckman, C.; Vandal, K.; Rouleau, P.; Talbot, M.; Tessier, P. A. Proinflammatory activities of S100: proteins S100A8, S100A9, and S100A8/A9 induce neutrophil chemotaxis and adhesion. J. Immunol. 2003, 170 (6), 3233-3242.

2. Nakatani, Y.; Yamazaki, M.; Chazin, W. J.; Yui, S. Regulation of S100A8/A9 (calprotectin) binding to tumor cells by zinc ion and its implication for apoptosis-inducing activity. Mediators Inflamm. 2005, 2005 (5), 280-292.

3. Champaiboon, C.; Sappington, K. J.; Guenther, B. D.; Ross, K. F.; Herzberg, M. C. Calprotectin S100A9 calcium-binding loops I and II are essential for keratinocyte resistance to bacterial invasion. J. Biol. Chem. 2009, 284 (11), 7078-7090. 
4. Björk, P.; Björk, A.; Vogl, T.; Stenström, M.; Liberg, D.; Olsson, A.; Roth, J.; Ivars, F.; Leanderson, T. Identification of human S100A9 as a novel target for treatment of autoimmune disease via binding to quinoline-3-carboxamides. PLoS biol. 2009, 7 (4), e1000097.

5. Koike, A.; Arai, S.; Yamada, S.; Nagae, A.; Saita, N.; Itoh, H.; Uemoto, S.; Totani, M.; Ikemoto, M. Dynamic mobility of immunological cells expressing S100A8 and S100A9 in vivo: a variety of functional roles of the two proteins as regulators in acute inflammatory reaction. Inflammation 2012, 35 (2), 409-419.

6. Simard, J.-C.; Simon, M.-M.; Tessier, P. A.; Girard, D. Damage-associated molecular pattern S100A9 increases bactericidal activity of human neutrophils by enhancing phagocytosis. J. Immunol. 2011, 186 (6), 3622-3631.

7. Ghavami, S.; Eshragi, M.; Ande, S. R.; Chazin, W. J.; Klonisch, T.; Halayko, A. J.; Mcneill, K. D.; Hashemi, M.; Kerkhoff, C.; Los, M. S100A8/A9 induces autophagy and apoptosis via ROS-mediated cross-talk between mitochondria and lysosomes that involves BNIP3. Cell Res. 2010, 20 (3), 314.

8. $\quad$ Park, K.; Kuechle, M. K.; Choe, Y.; Craik, C. S.; Lawrence, O. T.; Presland, R. B. Expression and characterization of constitutively active human caspase-14. Biochem. Biophys. Res. Commun. 2006, 347 (4), 941-948.

9. Yamamoto-Tanaka, M.; Makino, T.; Motoyama, A.; Miyai, M.; Tsuboi, R.; Hibino, T. Multiple pathways are involved in DNA degradation during keratinocyte terminal differentiation. Cell Death Dis. 2014, 5 (4), e1181.

10. Letronne, F.; Laumet, G.; Ayral, A.-M.; Chapuis, J.; Demiautte, F.; Laga, M.; Vandenberghe, M. E.; Malmanche, N.; Leroux, F.; Eysert, F. ADAM30 downregulates APP-linked defects through cathepsin D activation in Alzheimer's disease. EBioMedicine 2016, 9, 278-292.

11. Mayer, G.; Poirier, S.; Seidah, N. G. Annexin A2 is a C-terminal PCSK9-binding protein that regulates endogenous low density lipoprotein receptor levels. J. Biol. Chem. 2008, 283 (46), 31791-31801.

12. Seidah, N. G.; Poirier, S.; Denis, M.; Parker, R.; Miao, B.; Mapelli, C.; Prat, A.; Wassef, H.; Davignon, J.; Hajjar, K. A. Annexin A2 is a natural extrahepatic inhibitor of the PCSK9-induced LDL receptor degradation. PloS one 2012, 7 (7), e41865.

13. Ly, K.; Saavedra, Y. G. L.; Canuel, M.; Routhier, S.; Desjardins, R.; Hamelin, J.; Mayne, J.; Lazure, C.; Seidah, N. G.; Day, R. Annexin A2 reduces PCSK9 protein levels via 
a translational mechanism and interacts with the M1 and M2 domains of PCSK9. J. Biol. Chem. 2014, 289 (25), 17732-17746.

14. Zheng, B.; Matoba, Y.; Kumagai, T.; Katagiri, C.; Hibino, T.; Sugiyama, M. Crystal structure of SCCA1 and insight about the interaction with JNK1. Biochem. Biophys. Res. Commun. 2009, 380 (1), 143-147.

15. Lee, K. C.; Eckert, R. L. S100A7 (Psoriasin)-mechanism of antibacterial action in wounds. J. Invest. Dermatol. 2007, 127 (4), 945-957.

16. Gläser, R.; Harder, J.; Lange, H.; Bartels, J.; Christophers, E.; Schröder, J.-M. Antimicrobial psoriasin (S100A7) protects human skin from Escherichia coli infection. Nat. Immunol. 2005, 6 (1), 57.

17. Berthier, S.; Nguyen, M. V. C.; Baillet, A.; Hograindleur, M.-A.; Paclet, M.-H.; Polack, B.; Morel, F. Molecular interface of S100A8 with cytochrome b558 and NADPH oxidase activation. PLoS One 2012, 7 (7), e40277.

18. Ercolani, L.; Florence, B.; Denaro, M.; Alexander, M. Isolation and complete sequence of a functional human glyceraldehyde-3-phosphate dehydrogenase gene. J. Biol. Chem. 1988, 263 (30), 15335-15341.

19. Tisdale, E. J. Glyceraldehyde-3-phosphate dehydrogenase is phosphorylated by protein kinase $\mathrm{Cl} / \lambda$ and plays a role in microtubule dynamics in the early secretory pathway. J. Biol. Chem. 2002, 277 (5), 3334-3341.

20. Arif, A.; Chatterjee, P.; Moodt, R. A.; Fox, P. L. Heterotrimeric GAIT complex drives transcript-selective translation inhibition in murine macrophages. Mol. Cell. Biol. 2012, 32 (24), 5046-5055.

21. Zhang, S. Q.; Li, C. X.; Gao, X. Q.; Qiu, W. Y.; Chen, Q.; Li, X. M.; Zhou, X.; Tian, X.; Tang, Z. P.; Zhao, T. Identification and functional characterization of a novel transglutaminase 1 gene mutation associated with autosomal recessive congenital ichthyosis. Int. J. Dermatol. 2016, 55 (2), 201-207.

22. Galliano, M.-F.; Toulza, E.; Gallinaro, H.; Jonca, N.; Ishida-Yamamoto, A.; Serre, G.; Guerrin, M. A novel protease inhibitor of the $\alpha 2$-macroglobulin family expressed in the human epidermis. J. Biol. Chem. 2006, 281 (9), 5780-5789.

23. Ahvazi, B.; Kim, H. C.; Kee, S. H.; Nemes, Z.; Steinert, P. M. Three-dimensional structure of the human transglutaminase 3 enzyme: binding of calcium ions changes structure for activation. EMBO J. 2002, 21 (9), 2055-2067. 
24. Ahvazi, B.; Boeshans, K. M.; Idler, W.; Baxa, U.; Steinert, P. M. Roles of calcium ions in the activation and activity of the transglutaminase 3 enzyme. J. Biol. Chem. 2003, 278 (26), 23834-23841.

25. Munder, M.; Mollinedo, F.; Calafat, J.; Canchado, J.; Gil-Lamaignere, C.; Fuentes, J. M.; Luckner, C.; Doschko, G.; Soler, G.; Eichmann, K. Arginase I is constitutively expressed in human granulocytes and participates in fungicidal activity. Blood 2005, 105 (6), 2549-2556.

26. Munder, M.; Schneider, H.; Luckner, C.; Giese, T.; Langhans, C.-D.; Fuentes, J. M.; Kropf, P.; Mueller, I.; Kolb, A.; Modolell, M. Suppression of T-cell functions by human granulocyte arginase. Blood 2006, 108 (5), 1627-1634.

27. Oberlies, J.; Watzl, C.; Giese, T.; Luckner, C.; Kropf, P.; Müller, I.; Ho, A. D.; Munder, M. Regulation of NK cell function by human granulocyte arginase. J. Immunol. 2009, $182(9), 5259-5267$.

28. Masuda, Y.; Maeda, S.; Watanabe, A.; Sano, Y.; Aiuchi, T.; Nakajo, S.; Itabe, H.; Nakaya, K. A novel 21-kDa cytochrome c-releasing factor is generated upon treatment of human leukemia U937 cells with geranylgeraniol. Biochem. Biophys. Res. Commun. 2006, 346 (2), 454-460.

29. Oakley, A. J.; Yamada, T.; Liu, D.; Coggan, M.; Clark, A. G.; Board, P. G. The identification and structural characterization of C7orf24 as $\gamma$-glutamyl cyclotransferase an essential enzyme in the $\gamma$-glutamyl cycle. J. Biol. Chem. 2008, 283 (32), 22031-22042.

30. Huang, F.; Kirkpatrick, D.; Jiang, X.; Gygi, S.; Sorkin, A. Differential regulation of EGF receptor internalization and degradation by multiubiquitination within the kinase domain. Mol. Cell 2006, 21 (6), 737-748.

31. Komander, D. The emerging complexity of protein ubiquitination. Biochem. Soc. Trans. 2009, 37 (5), 937-953.

32. Kang, S. W.; Chae, H. Z.; Seo, M. S.; Kim, K.; Baines, I. C.; Rhee, S. G. Mammalian peroxiredoxin isoforms can reduce hydrogen peroxide generated in response to growth factors and tumor necrosis factor- $\alpha$. J. Biol. Chem. 1998, 273 (11), 6297-6302.

33. Ovaere, P.; Lippens, S.; Vandenabeele, P.; Declercq, W. The emerging roles of serine protease cascades in the epidermis. Trends Biochem. Sci. 2009, 34 (9), 453-463.

34. Brown, S. J.; McLean, W. I. One remarkable molecule: filaggrin. J. Invest. Dermatol. 2012, $132(3), 751-762$. 
35. Bao, Y.; Bing, C.; Hunter, L.; Jenkins, J. R.; Wabitsch, M.; Trayhurn, P. Zinc- $\alpha 2-$ glycoprotein, a lipid mobilizing factor, is expressed and secreted by human (SGBS) adipocytes. FEBS Lett. 2005, 579 (1), 41-47.

36. Ohkubo, I.; Niwa, M.; Takashima, A.; Nishikimi, N.; Gasa, S.; Sasaki, M. Human seminal plasma $\mathrm{Zn}-\alpha 2$-glycoprotein: Its purification and properties as compared with human plasma Zn-ß2-glycoprotein. Biochim. Biophys. Acta 1990, 1034 (2), 152-156.

37. Araki, T.; Gejyo, F.; Takagaki, K.; Haupt, H.; Schwick, H. G.; Bürgi, W.; Marti, T.; Schaller, J.; Rickli, E.; Brossmer, R. Complete amino acid sequence of human plasma Zn-alpha 2-glycoprotein and its homology to histocompatibility antigens. Proc. Natl. Acad. Sci. 1988, 85 (3), 679-683.

38. Sánchez, L. M.; Chirino, A. J.; Bjorkman, P. J. Crystal structure of human ZAG, a fat-depleting factor related to MHC molecules. Science 1999, 283 (5409), 1914-1919.

39. Blaydon, D. C.; Nitoiu, D.; Eckl, K.-M.; Cabral, R. M.; Bland, P.; Hausser, I.; van Heel, D. A.; Rajpopat, S.; Fischer, J.; Oji, V. Mutations in CSTA, encoding Cystatin A, underlie exfoliative ichthyosis and reveal a role for this protease inhibitor in cell-cell adhesion. Am. J. Hum. Genet. 2011, 89 (4), 564-571.

40. Ding, J.; Wang, K.; Liu, W.; She, Y.; Sun, Q.; Shi, J.; Sun, H.; Wang, D.-C.; Shao, F. Pore-forming activity and structural autoinhibition of the gasdermin family. Nature 2016, 535 (7610), 111.

41. Kuwabara, I.; Kuwabara, Y.; Yang, R.-Y.; Schuler, M.; Green, D. R.; Zuraw, B. L.; Hsu, D. K.; Liu, F.-T. Galectin-7 (PIG1) exhibits pro-apoptotic function through JNK activation and mitochondrial cytochrome cRelease. J. Biol. Chem. 2002, 277 (5), 3487-3497.

42. Hsu, C.-Y.; Henry, J.; Raymond, A.-A.; Méchin, M.-C.; Pendaries, V.; Nassar, D.; Hansmann, B.; Balica, S.; Schiltz, O.; Schmitt, A.-M. Deimination of human filaggrin-2 promotes its proteolysis by calpain 1. J. Biol. Chem. 2011, jbc. M110. 197400.

43. Sorimachi, H.; Ohmi, S.; Emori, Y.; Kawasaki, H.; Saido, T.; Ohno, S.; Minami, Y.; Suzuki, K. A novel member of the calcium-dependent cysteine protease family. Biol. Chem. Hoppe Seyler 1990, 371, 171-176.

44. Ziveri, J.; Tros, F.; Guerrera, I. C.; Chhuon, C.; Audry, M.; Dupuis, M.; Barel, M.; Korniotis, S.; Fillatreau, S.; Gales, L. The metabolic enzyme fructose-1, 6-bisphosphate aldolase acts as a transcriptional regulator in pathogenic Francisella. Nat. Commun. 2017, 8 (1), 853 . 
45. Takeuchi, A.; Miyamoto, T.; Yamaji, K.; Masuho, Y.; Hayashi, M.; Hayashi, H.; Onozaki, K. A human erythrocyte-derived growth-promoting factor with a wide target cell spectrum: identification as catalase. Cancer Res. 1995, 55 (7), 1586-1589.

46. Gitler, C.; Zarmi, B.; Kalef, E.; Meller, R.; Zor, U.; Goldman, R. Calciumdependent oxidation of thioredoxin during cellular growth initiation. Biochem. Biophys. Res. Commun. 2002, 290 (2), 624-628.

47. Kallio, H.; Tolvanen, M.; Jänis, J.; Pan, P.-w.; Laurila, E.; Kallioniemi, A.; Kilpinen, S.; Tuominen, V. J.; Isola, J.; Valjakka, J. Characterization of non-specific cytotoxic cell receptor protein 1: a new member of the lectin-type subfamily of F-box proteins. PloS one 2011, 6 (11), e27152.

48. Dana, R. C.; Welch, W. J.; Deftos, L. J. Heat shock proteins bind calcitonin. Endocrinology 1990, 126 (1), 672-674.

49. Oka, O. B. V.; Pringle, M. A.; Schopp, I. M.; Braakman, I.; Bulleid, N. J. ERdj5 is the ER reductase that catalyzes the removal of non-native disulfides and correct folding of the LDL receptor. Mol. Cell 2013, 50 (6), 793-804.

50. Linse, S.; Helmersson, A.; Forsen, S. Calcium binding to calmodulin and its globular domains. J. Biol. Chem. 1991, 266 (13), 8050-8054.

51. Lacombe, A.; Lee, H.; Zahed, L.; Choucair, M.; Muller, J.-M.; Nelson, S. F.; Salameh, W.; Vilain, E. Disruption of POF1B binding to nonmuscle actin filaments is associated with premature ovarian failure. Am. J. Hum. Genet. 2006, 79 (1), 113-119.

52. Padovano, V.; Lucibello, I.; Alari, V.; Della Mina, P.; Crespi, A.; Ferrari, I.; Recagni, M.; Lattuada, D.; Righi, M.; Toniolo, D. The POF1B candidate gene for premature ovarian failure regulates epithelial polarity. J. Cell. Sci. 2011, 124 (19), 3356-3368.

53. Koster, J.; Geerts, D.; Favre, B.; Borradori, L.; Sonnenberg, A. Analysis of the interactions between BP180, BP230, plectin and the integrin $\alpha 6 \beta 4$ important for hemidesmosome assembly. J. Cell. Sci. 2003, 116 (2), 387-399.

54. Kaczocha, M.; Vivieca, S.; Sun, J.; Glaser, S. T.; Deutsch, D. G. Fatty acid-binding proteins transport $\mathrm{N}$-acylethanolamines to nuclear receptors and are targets of endocannabinoid transport inhibitors. J. Biol. Chem. 2012, 287 (5), 3415-3424.

55. Siegenthaler, G.; Hotz, R.; Chatellard-Gruaz, D.; Didierjean, L.; Hellman, U.; Saurat, J. Purification and characterization of the human epidermal fatty acid-binding protein: localization during epidermal cell differentiation in vivo and in vitro. Biochem. J. 1994, 302 (2), 363-371. 
56. Tanco, S.; Zhang, X.; Morano, C.; Avilés, F. X.; Lorenzo, J.; Fricker, L. D. Characterization of the substrate specificity of human carboxypeptidase A4 and implications for a role in extracellular peptide processing. J. Biol. Chem. 2010, 285 (24), 18385-18396.

57. Groettrup, M.; Soza, A.; Eggers, M.; Kuehn, L.; Dick, T. P.; Schild, H.; Rammensee, H.-G.; Koszinowski, U. H.; Kloetzel, P.-M. A role for the proteasome regulator PA28 $\alpha$ in antigen presentation. Nature 1996, 381 (6578), 166.

58. Yano, M.; Koumoto, Y.; Kanesaki, Y.; Wu, X.; Kido, H. 20S proteasome prevents aggregation of heat-denatured proteins without PA700 regulatory subcomplex like a molecular chaperone. Biomacromolecules 2004, 5 (4), 1465-1469.

59. Rut, W.; Drag, M. Human 20S proteasome activity towards fluorogenic peptides of various chain lengths. Biol. Chem. 2016, 397 (9), 921-926.

60. Touitou, R.; Richardson, J.; Bose, S.; Nakanishi, M.; Rivett, J.; Allday, M. J. A degradation signal located in the C-terminus of $\mathrm{p} 21 \mathrm{WAF} 1 / \mathrm{CIP} 1$ is a binding site for the $\mathrm{C} 8 \alpha$ subunit of the 20S proteasome. EMBO J. 2001, 20 (10), 2367-2375.

61. Apcher, G. S.; Heink, S.; Zantopf, D.; Kloetzel, P.-M.; Schmid, H.-P.; Mayer, R. J.; Krüger, E. Human immunodeficiency virus-1 Tat protein interacts with distinct proteasomal $\alpha$ and $\beta$ subunits. FEBS Lett. 2003, 553 (1-2), 200-204.

62. Sasaki, M.; Sukegawa, J.; Miyosawa, K.; Yanagisawa, T.; Ohkubo, S.; Nakahata, N. Low expression of cell-surface thromboxane A2 receptor $\beta$-isoform through the negative regulation of its membrane traffic by proteasomes. Prostaglandins Other Lipid Mediat. 2007, 83 (4), 237-249.

63. Ait-El-Mkadem, S.; Dayem-Quere, M.; Gusic, M.; Chaussenot, A.; Bannwarth, S.; François, B.; Genin, E. C.; Fragaki, K.; Volker-Touw, C. L.; Vasnier, C. Mutations in MDH2, encoding a Krebs cycle enzyme, cause early-onset severe encephalopathy. The Am. J. Hum. Genet. 2017, 100 (1), 151-159.

64. Vostal, J. G.; Shulman, N. R. Vinculin is a major platelet protein that undergoes Ca2+-dependent tyrosine phosphorylation. Biochem. J. 1993, 294 (3), 675-680.

65. Cho, S.; Choi, Y.-J.; Kim, J.-M.; Jeong, S.-T.; Kim, J.-H.; Kim, S.-H.; Ryu, S.-E. Binding and regulation of HIF-1 $\alpha$ by a subunit of the proteasome complex, PSMA7. FEBS Lett. 2001, 498 (1), 62-66.

66. Krüger, M.; Beger, C.; Welch, P. J.; Barber, J. R.; Manns, M. P.; Wong-Staal, F. Involvement of proteasome $\alpha$-subunit PSMA7 in hepatitis C virus internal ribosome entry site-mediated translation. Mol. Cell. Biol. 2001, 21 (24), 8357-8364. 
67. Lin, H.-K.; Altuwaijri, S.; Lin, W.-J.; Kan, P.-Y.; Collins, L. L.; Chang, C. Proteasome activity is required for androgen receptor transcriptional activity via regulation of androgen receptor nuclear translocation and interaction with coregulators in prostate cancer cells. J. Biol. Chem. 2002, 277 (39), 36570-36576.

68. Jia, Y.; Song, T.; Wei, C.; Ni, C.; Zheng, Z.; Xu, Q.; Ma, H.; Li, L.; Zhang, Y.; He, X. Negative regulation of MAVS-mediated innate immune response by PSMA7. $J$. Immunol. 2009, 183 (7), 4241-4248.

69. Du, H.; Huang, X.; Wang, S.; Wu, Y.; Xu, W.; Li, M. PSMA7, a potential biomarker of diseases. Protein Pept. Lett. 2009, 16 (5), 486-489.

70. Sanvito, F.; Piatti, S.; Villa, A.; Bossi, M.; Lucchini, G.; Marchisio, P. C.; Biffo, S. The $\beta 4$ integrin interactor p27BBP/eIF6 is an essential nuclear matrix protein involved in 60S ribosomal subunit assembly. J. Cell Biol. 1999, 144 (5), 823-838.

71. Ceci, M.; Gaviraghi, C.; Gorrini, C.; Sala, L. A.; Offenhäuser, N.; Marchisio, P. C.; Biffo, S. Release of eIF6 (p27 BBP) from the 60S subunit allows 80S ribosome assembly. Nature 2003, 426 (6966), 579.

72. Chendrimada, T. P.; Finn, K. J.; Ji, X.; Baillat, D.; Gregory, R. I.; Liebhaber, S. A.; Pasquinelli, A. E.; Shiekhattar, R. MicroRNA silencing through RISC recruitment of eIF6. Nature 2007, 447 (7146), 823.

73. Finch, A. J.; Hilcenko, C.; Basse, N.; Drynan, L. F.; Goyenechea, B.; Menne, T. F.; Fernández, Á. G.; Simpson, P.; D'Santos, C. S.; Arends, M. J. Uncoupling of GTP hydrolysis from eIF6 release on the ribosome causes Shwachman-Diamond syndrome. Genes Dev. 2011, 25 (9), 917-929.

74. Galjart, N. J.; Morreau, H.; Willemsen, R.; Gillemans, N.; Bonten, E.; d'Azzo, A. Human lysosomal protective protein has cathepsin A-like activity distinct from its protective function. J. Biol. Chem. 1991, 266 (22), 14754-14762.

75. Jae, L. T.; Raaben, M.; Herbert, A. S.; Kuehne, A. I.; Wirchnianski, A. S.; Soh, T. K.; Stubbs, S. H.; Janssen, H.; Damme, M.; Saftig, P. Lassa virus entry requires a triggerinduced receptor switch. Science 2014, 344 (6191), 1506-1510. 